DEPARTMENT OF THE INTERIOR

UNITED STATES GEOLOGICAL SURVEY

GEOLOGIC MAP OF THE CROZIER PEAK QUADRANGLE, PINAL COUNTY, ARIZONA

By Medora H. Krieger 


\title{
GEOLOGIC MAP OF THE CROZIER PEAK QUADRANGLE, PINAL COUNTY, ARIZONA
}

\author{
By Medora H. Krieger
}

\section{REGIONAL GEOLOGIC SETTING}

The broad regional geologic and structural setting of the Winkelman quadrangle, of which the Crozier Peak quadrangle is the northeast part, is discussed by Krieger (1974). Rocks within the general area range from Precambrian to Holocene, and all units are represented in this quadrangle except the Naco and Quiburis Formations. It is one of the most structurally complex quadrangles within the region.

\section{STRATIGRAPHY}

The oldest Precambrian rocks in the area of the larger scale index map are the Pinal Schist and intrusive rocks, largely the Ruin Granite (Oracle Granite of N.P. Peterson, 1938). Batholithic masses of Ruin Granite (1,430 m.y.) were intruded after a period of intense deformation that produced near-vertical east-trending foliation and bedding in the schist. The schist and granite are overlain with profound angular unconformity by Precambrian sedimentary rocks--the Apache Group and the disconformably overlying Troy Quartzite. Diabase, about 1,200 m.y. old (Silver, 1960; Damon and others, 1962), forms sills in the Apache Group and Troy Quartzite, sill-like masses in the schist and granite generally parallel to, and not more than 500 feet below, the pre-Apache surface (Shride, 1967, p. 56), and some dikes. The sills inflated, but did not perceptibly tilt, the Precambrian sedimentary rocks.

After a long period of erosion, Paleozoic formations were deposited paraconformably on the Precambrian sedimentary rocks.

Volcanic rocks of Late Cretaceous age disconformably overlie older rocks in the general area. In the Crozier Peak quadrangle they are the Williamson Canyon Volcanics of andesitic composition and a rhyodacitic to quartz latitic pyroclastic unit recognized only in the northwest part of the Crozier Peak quadrangle. The Williamson Canyon Volcanics have been considered either Late Cretaceous (Willden, 1964) or Late Cretaceous and(or) early Tertiary (Simons, 1964, Creasey, 1965, 1967). They are now considered Late Cretaceous because in the northeast part of the Crozier Peak quadrangle they are intruded by diorite that in the

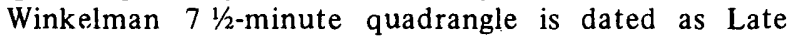
Cretaceous. The rhyodacitic to quartz latitic volcanic units are also considered Late Cretaceous because some of it resembles the Glory Hole Volcanics (Simons, 1964; Krieger, 1968b), which is intruded by granodiorite dated as. 69 m.y. (Creasey, 1967).

Late Cretaceous diorite and granodiorite and Late Cretaceous and(or) early Tertiary (Laramide porphyry masses of several lithologic types) intrude the older rocks.

Cenozoic stratigraphy in eastern Pinal County has recently been revised by Krieger and others (1974). In the area of the larger scale index map Tertiary sedimen- tary deposits, formerly called Gila Conglomerate or Group, are now divided into three formations--in ascending order, the San Manuel, Big Dome, and Quiburis. In addition, Pleistocene and Holocene alluvial deposits, also formerly included in the Gila Conglomerate or Group, overlie these formations.

The San Manuel Formation consists of alluvial, lacustrine(?) and playa deposits, and interbedded andesite and megabreccias. It is Miocene (probably early Miocene) in age. Discordant dates on biotite and sanidine from a rhyodacite tuff bed in its upper part are 18 and $24 \mathrm{~m}$.y., respectively (Joan Engels, written communication, 1968). The San Manuel Formation is unconformably overlain by the alluvial Big Dome Formation. In the Kearny quadrangle an interbedded nonwelded ash-flow yields late Miocene K-Ar ages of $14 \mathrm{~m} . \mathrm{y}$. on biotite and $17 \mathrm{~m} . \mathrm{y}$. on hornblende (Cornwall and others, 1971, and Banks, 1972). The youngest of these formations, the Quiburis Formation, which consists of an alluvial and a lakebed facies, was deposited in the basin now occupied by the San Pedro River. It contains Hemphillian vertebrate fossils (see Krieger, 1974a), indicating a middle Pliocene age.

\section{STRUCTURE}

The major structural features in the Winkelman 15minute quadrangle southwest of the Gila and San Pedro Rivers are high-angle faults, north-northwesttrending en echelon ridges of steeply dipping to overturned diabase and Precambrian and Paleozoic sedimentary rocks, and low-angle gravity slides. As the tops of the beds in the en echelon ridges always face east, the structures are interpreted as partly eroded roots of a single monoclinal fold later separated by faults, or possibly as a series of monoclinal folds. Locally, the section within an individual ridge is repeated along what appears on a map as a high-angle fault, but which is inferred to be a tilted thrust. Some of the faulting, monoclinal folding, tilting of the thrusts, uplift, and the erosion of large areas now stripped of Precambrian and Paleozoic sedimentary rocks occurred before deposition of the San Manuel Formation, for the oldest unit in that formation in the Putnam Wash quadrangle is composed largely of Precambrian granitic clasts. Intense deformation also occurred after deposition of the San Manuel Formation, for adjacent to the monoclinal ridges, the formation dips steeply though somewhat less than the older rocks. The formation also has been cut by low-angle gravity slides and high-angle faults.

Faults that predate the San Manuel Formation are the thrusts, now tilted to vertical or overturned, and two sets of high-angle faults that trend east-northeast. Some east-northeast-trending faults resemble tear faults related to thrusting.

The Ripsey Wash fault, a tilted thrust, is a multiplestrand fault, in contrast to the Romero Wash fault in the Winkelman $71 / 2$-minute quadrangle, which is a single 
strand fault. The fault zone consists of near-vertical, north-trending, east-facing slivers of basal Apache Group rocks that rest on granite and lie west of granite that underlies the main outcrops of the Apache Group. West of the point where the monoclinal swings abruptly east, successive slivers of basal Apache overlying granite too small to map are repeated in close succession by parallel faults. The long north-trending diabase masses in granite, apparently well below the pre-Apache surface, also suggests repetition by thrusting. Although there is no surface expression of the thrusts, the diabase is inferred to be sill-like masses that were intruded not more than 500 feet below the pre-Apache surface. Exposures in the area of the Ripsey Wash fault are mostly poor; many areas mapped as granite are covered by thin films of alluvium; some may conceal Apache Group rocks.

Faults that postdate the San Manuel Formation are west-dipping, low-angle gravity slides, high-angle, northnorthwest-trending faults, and a few east-northeasttrending faults. Some high-angle faults, or some of the movement on them, postdate the Big Dome Formation; a few postdate the Quiburis Formation. The Indian Camp fault in the northeast part of the quadrangle may be a gravity slide similar to a major feature in the Putnam Wash quadrangle.

Although the monoclinal structures may have formed as separate en echelon folds, the alternative suggestion of a single monocline, later separated by faulting, is appealing. In the Crozier Peak quadrangle, the southern end of the ridge of steeply overturned strata swings abruptly east and abuts Ruin Granite, suggesting a strike-slip fault that caused the abrupt change in strike and dip of the Precambrian sedimentary rocks and separated the segment in the Winkelman quadrangle from the one in the Crozier Peak quadrangle. The segments were further separated by north-trending, high-angle faults. How much of the movement on the strike-slip and north-trending faults is older than the San Manuel Formation and how much is younger is uncertain. The fold in the older rocks is reflected in the younger deposits, which also swing east. Additional evidence for major strike-slip faulting is: (1) the easttrending high-angle faults and low-angle shear zones that separate Ruin Granite from diorite and Williamson Canyon Volcanics in the northeastern part of the Crozier Peak quadrangle, and (2) the fractured condition of the rocks in the north east corner of the Crozier Peak quadrangle that extends into the Kearny quadrangle. In this area of at least a square mile, few pieces on the surface are more than 6 inches in diameter and fractures are filled with carbonate, manganese minerals, specular hematite, and locally pyrite. Apache Group rocks are not in a normal sedimentary sequence. Other masses of brecciated rock with attendant chaotic repetition of small masses of Apache Group rocks and granite occur just north and northeast of the Crozier Peak quadrangle.

\section{MINERALIZATION}

The Winkelman 15-minute quadrangle, of which the Crozier Peak is a part, is adjacent to three major copper deposits: the San Manuel to the southeast, the Christmas to the northeast, and the Ray to the northwest. Although no economic deposits have yet been found within the 15-minute quadrangle, numerous prospect pits, shafts, and adits have explored the principal mineralized areas, which are in granitic rocks in the southeast corner and in the north-central and northwestern parts of the 15-minute quadrangle. Some of the mineralization may be Precambrian in age, but most of it probably is related to Laramide intrusive bodies.

In the Crozier Peak quadrangle, mineralization is confined to the Ruin Granite and Cretaceous diorite in the northeast part of the area and to Ruin Granite elsewhere. In the northeast corner, brecciated areas are veined with calcite, manganese oxide, specular variety of hematite, and goethite. Pyrite and copper staining is common in diorite. Quartz-sericite alteration with disseminated pyrite and a little copper mineralization is common in the northwest part of the quadrangle. In the southwestern part, two ages of quartz veins were noted: those that are older than the Precambrian diabase and those that are younger, probably of Laramide age. The younger quartz veins strike eastward, generally are 1 to 2 inches wide, locally 12 inches wide, and contain small pyrite cubes (as much as $4 \mathrm{~mm}$ ). Associated with some of the shear zones and Laramide dikes are veins of calcite; one in the southeast corner of the quadrangle 5 to 10 feet wide, locally 20 feet wide, consists of coarsely crystalline (at least $1 \mathrm{~cm}$ ) white and brown calcite and finer grained (less than $2 \mathrm{~mm}$ ) pink calcite. Pink and white calcite are veined by brown calcite that has about the grain size of the pink calcite. X-ray examination proved that all the carbonate is calcite.

\section{DESCRIPTION OF MAP UNITS}

\section{SURFICIAL DEPOSITS}

Alluvium (0-15 ft exposed).-Flood-plain deposits along valley bottoms composed of clay, silt, sand, and some gravel; largely unconsolidated.

Talus (0-20 ft).-Veneer of rock debris derived from adjacent bedrock. Many talus deposits, not identified on map, partly cover diabase, upper member of Dripping Spring Quartzite, and Pioneer Formation.

Soil and gravel veneer on pediments and younger terraces $(0-25 \mathrm{ft})$. - Subangular pebbles and cobbles in a generally reddish brown, fine- to coarse-grained matrix. Originally covered wide areas west and south of Ripsey Hill ridge, where present surface is only. slightly below the pediment suirface. The dark-red-brown soils were developed during one of the pre-Wisconsin interglaciations.

Undifferentiated gravel. - Terrace or pediment gravels, talus, and alluvium; includes isolated exposures of underlying rocks.

\section{SAND AND GRAVEL (0-MORE THAN 100 FT EXPOSED)}

Poorly consolidated alluvial gravel and sand composed largely of granules and small pebbles in a finer grained matrix, derived largely from Ruin Granite and related rocks. Concealed in many places by alluvial and colluvial material on valley bottoms and slopes and by red soil developed on upper (pediment) surfaces. Gravels east of Hackberry Wash in the northern part of the quadrangle were deposited in channels that were cut in the San Manuel Formation during the formation of the present drainage system. Sand and gravel in the 
southwestern part of the map area and east of Ripsey Ranch are tentatively included in this unit. Some or all of them may belong to an older formation.

\section{BIG DOME FORMATION}

(Thickness unknown, probably not more than a few hundred feet in this area). Named by Krieger and others (1974) for exposures at Big Dome, Sonora quadrangle, where it was mapped but not named by Cornwall and others(1971). Yellowish-gray, pale-olive, to grayish-orange pink; derived largely from Oracle Granite in the Crozier Peak quadrangle. Some lenses contain scattered to abundant clasts of diabase, Precambrian and Paleozoic sedimentary rocks and Late Cretaceous and(or) early Tertiary rocks, generally in a granitic matrix; local beds of rhyolite tuff. Clasts generally pebble to cobble sized, local large boulders; mostly subangular to subrounded. Well indurated along Hackberry Wash; elsewhere poorly indurated and poorly exposed.

For a short distance along Hackberry Wash south of its junction with Eagle Wash, an angular unconformity between gently dipping Big Dome Formation and more steeply dipping San Manuel Formation is exposed. Because of relief on the underlying gravel surface and the presence of several faults of small displacement, the unconformity was clearly recognizable only in this local area. Elsewhere, the contact between the two formations is very arbitrarily located, as compositions and bedding features are very similar. Where the unconformity is exposed, the Big Dome Formation is a little yellower in color and slightly finer grained than the underlying San Manuel Formation. The unit mapped as Big Dome Formation includes the poorly exposed ridge-top gravels, which could be weathered and slumped San Manuel Formation or younger sand and gravel.

\section{SAN MANUEL FORMATION}

Thickness unknown, but at least $6,000 \mathrm{ft}$.-Named by Heindl (1963). Divided into following units in this quadrangle:

Granitic alluvial deposits (thickness unknown, possibly 1,000 to 2,000 ft). - Yellowish-gray, pale-olive, to grayish-orange-pink; derived largely from Ruin Granite and related rocks: granitic material largely light colored, locally red; some lenses with scattered to abundant clasts of Precambrian and Paleozoic sedimentary rocks, Late Cretaceous and(or) early Tertiary intrusive rocks, and Late Cretaceous or Tertiary andesite, generally in a granitic matrix. Local beds of rhyolite and rhyodacite tuff, concretionary tuff, and sandy beds with small rhyolite(?) lapilli. Table 1 gives chemical and normative compositions and location of the rhyodacite tuff bed from which K-Ar ages of 18 (on biotite) and 24 (on sanidine) m.y. were obtained. Clasts generally pebble to cobble sized, but some are $10 \mathrm{ft}$ long; subangular to subrounded, except for angular cobbles and boulders of granite and Paleozoic rocks north of the east end of east-trending ridge of Precambrian sedimentary rocks. Interbeds of sand-sized particles, with or without scattered pebbles and cobbles, are mostly well and thin bedded; some can be traced for several hundred feet at least. In many places bedding is poor to indistinct, especially in southern part of area, and on ridge tops, where the unit is poorly indurated and poorly exposed. Beds with nongranitic material may be more indurated than adjacent granitic gravels. Near granitic bedrock, some granite clasts may have accumulated as talus. Near junction of Hackberry and Eagle Washes, well-bedded and well-indurated material, with few clasts larger than small cobbles, resembles the playa(?) deposits near Beehive Well on Putnam Wash.

TABLE 1.-Chemical and normative composition of rhyodacite tuff bed on north side of Jim Thomas Wash, east edge of sec. 19, T. 5 S., R. 14 E.

[Analysis under direction of Leonard Shapiro, methods given in U.S. Geol. Survey Bull. 1144-A]

\begin{tabular}{|c|c|c|c|}
\hline \multicolumn{4}{|c|}{ Field No. W-158 } \\
\hline \multicolumn{2}{|c|}{$\begin{array}{l}\text { Chemical composition } \\
\text { (in percent) }\end{array}$} & \multicolumn{2}{|c|}{$\begin{array}{l}\text { CIPW norms } \\
\text { (wt percent) }\end{array}$} \\
\hline $\mathrm{SiO}_{2}$ & 59.4 & Q & 32.0 \\
\hline $\mathrm{Al}_{2} \mathrm{O}_{3}$ & 15.8 & C. & 4.2 \\
\hline $\mathrm{Fe}_{2} \mathrm{O}_{3}$ & 2.2 & or & 8.6 \\
\hline $\mathrm{Fe} 0$ & 1.7 & $a b$ & 24.5 \\
\hline Mg0 & 2.0 & an & 19.2 \\
\hline $\mathrm{CaO}$ & 3.7 & en & 5.6 \\
\hline $\mathrm{Na}_{2} \mathrm{O}$ & 2.6 & fo & .5 \\
\hline $\mathrm{K}_{2} \mathbf{O}$ & 1.3 & $\mathrm{mt}$ & 3.6 \\
\hline $\mathrm{H}_{2} \mathrm{O}-$ & 4.6 & il & 1.4 \\
\hline \multirow{3}{*}{$\begin{array}{l}\mathrm{H}_{2} \mathrm{O}+ \\
\mathrm{TiO}_{2} \\
\mathrm{P}_{2} \mathrm{O}_{5}\end{array}$} & \multirow{3}{*}{$\begin{array}{l}5.6 \\
.64 \\
.17\end{array}$} & ap & .5 \\
\hline & & Total & 100 \\
\hline & & \multirow{3}{*}{$\begin{array}{l}\text { Salic } \\
\text { Femic }\end{array}$} & \\
\hline Mn0 & .12 & & $\begin{array}{l}88.0 \\
11.4\end{array}$ \\
\hline $\mathrm{CO}_{2}$ & $<.05$ & & 11.4 \\
\hline Sum & 100 & \multicolumn{2}{|c|}{$\begin{array}{l}\text { In calculating the norm, } \\
\text { both } \mathrm{H}_{2} \mathrm{O}+\text { and } \mathrm{H}_{2} \mathrm{O} \text { - were } \\
\text { omitted }\end{array}$} \\
\hline
\end{tabular}

Nongranitic alluvial deposits.-Present in two areas: (1) larger area lies east of the granitic deposits; (2) smaller area underlies granitic deposits on east side of Ripsey Hill ridge.

Larger area.-(Thickness probably as much as $3,000 \mathrm{ft}$ based on outcrop width and attitude, if not repeated by faults.) Pale-brown, brownish-gray, and olive-gray, locally grayish-red, especially in northeastern exposures. Angular to subrounded clasts, from silt to boulders as much as $8 \mathrm{ft}$ in longest dimension; composed of fragments of Paleozoic limestone and sandstone and Precambrian sedimentary rocks and diabase. Clasts of Williamson Canyon Volcanics or various Laramide intrusive rocks locally abundant near the contacts with these rocks. A few beds near the southeast margin contain granitic clasts. Escabrosa Limestone usually forms the largest clasts. Boulders generally are erratically distributed; bedding is poorly developed, especially in southern exposures, where ratio of sand and silt to clasts is small. Shallow channels are fairly common. Some beds, especially in northern exposures, are fairly well sorted with abundant closely packed, 2- to 4-in. pebbles. The formation is more indurated in the northern part of the quadrangle than in the southern part. The unit is part of a large area of dark non granitic alluvial deposits that are well exposed in the Kearny quadrangle and that grade into dark nongrasitic playa deposits, similar to the nongranitic playa deposits in the Crozier Peak quadrangle. 
Smaller area.-(Thickness probably as much as 1,000 $\mathrm{ft}$, based on attitude and outcrop width.) Coarse-grained and brown to yellowish brown in the western part, somewhat finer grained and yellowish gray to pale olive to the east. Composed of fragments from Precambrian diabase and sedimentary rocks, Paleozoic limestone and sandstone, and Tertiary(?) mafic volcanic rocks, with local lenses containing clasts of Ruin Granite and Late Cretaceous volcanic and Laramide intrusive rocks.

Nongranitic playa deposits. - Beds up to 12 in. thick of light-olive-gray to light-brownish-gray sand and silt, alternating with conglomerate (mostly pebble sized). Same as the dark nongranitic playa deposits in the Kearny quadrangle.

Andesitic volcanic rocks. - Andesite or basalt crops out along the east side of Ripsey Hill ridge from upper Jim Thomas Wash,NW1/4 sec. 30, T. 5 S., R. 14 E., south for 2.3 miles; it is also exposed east of Jim Thomas Wash in sec. 20, T. 5 S., R. 14 E. Along upper Jim Thomas Wash near-vertical, north-trending flows, about $300 \mathrm{ft}$ thick, are dark gray and porphyritic, containing abundant 1.2 $\mathrm{mm}$ phenocrysts of light-brown olivine, pyroxene; and magnetite in a very fine grained groundmass of plagioclase laths, pyroxene, altered olivine, and magnetite. The unit consists of several flows with brecciated tops and bottoms that clearly flowed out over and baked the underlying gravels (to west). Locally, contact between andesite and overlying gravels is a high-angle fault; in other places, the contact appears to be sedimentary. Narrow band of andesite, extending south from near the center of sec. 31 , T. 5 S., R. 14 E., tentatively correlated with the flows to the north. It is medium light gray, finely vesticular, and contains fewer phenocrysts than the flows to the north. Phenocrysts are hornblende and biotite, largely altered to granular magnetite, and a few fresh pyroxenes. Groundmass is altered, but plagioclase laths and mafic minerals are recognizable. East of lower Jim Thomas Wash lightbrownish-gray vesicular andesite has phenocrysts to $2 \mathrm{~mm}$ in diameter of alterde mafic minerals (olivine?) in a groundmass of plagioclase laths, pyroxene, and altered olivine. It closely resembles some of the andesite of Depression Canyon (of the Galiuro Volcanics), especially the thin flows between Bear Springs and Whitewash Canyons that are about 25 m.y. old (Krieger, 1968a).

Megabreccia.-Lenses of megabreccia interbedded in granitic and nongranitic alluvial deposits; extremely well indurated, especially those composed of quartzite and limestone; mostly angular to subangular fragments in a matrix of ground-up material of the same composition. Probably formed as landslide blocks. Essentially monolithologic breccias of Ruin Granite occur in granitic and nongranitic deposits east of Ripsey Hill ridge. Small amounts of breccias of Precambrian sedimentary rocks and diabase are locally associated with them. Intermittent lenses of breccia, largely of Escabroas Limestone, in nongranitic deposits from north edge of map area on both sides of Jim Thomas Wash southward for nearly $1 \frac{1 / 2}{2}$ miles to east of Hackberry Wash near west edge. of sec. 21, T. 5 S., R. 14 E. They are the southern end of extensive breccias interbedded in playa and alluvial deposits and composed of daiabas, Precambrian and Paleozoic sedimentary rocks, Late Cretaceous volcanic rocks, and Laramide intrusive rocks that extend north of the map area for more than 2 miles.

A north-northwest-trending compound lens of breccia, bounded on the west by a fault, separates granitic from nongranitic deposits between Jim Thomas and Hackberry Washes. Although most of the area is brecciated, at the highest point on the ridge, the lower member of the Abrigo Formation apparently rests conformably on upper member of the Troy Quartzite; neither unit appears to be appreciably brecciated. Other quartzite and the limestone masses are good monolithologic breccia. The base of the unit is a diabase breccia that rests on a thin layer of undisturbed sand and gravel, above unbrecciated andesitic flows.

The breccia mass east of Ripsey Hill ridge near the northern part of the area is a jumble of Dripping Spring and Troy Quartzites, diabase, Mescal Limestone, and basalt; some of it is not appreciably brecciated. The small lens of Escabrosa and Martin, shown as monolithologic breccia in $\mathrm{NW}^{1 / 4} \mathrm{sec} .19$, T. $5 \mathrm{~S}$., R. $14 \mathrm{E}$., may be a landslide block younger than the tilted gravels, or it may result from unrecognized faults.

Along the north side of the diorite mass, between Indian Camp and Eagle Washes, brecciated diorite diorite grades northward into talus and sedimentary breccia and into nongranitic alluvial deposits composed largely of diorite. In some of the breccia just west of Indian Camp Wash, clasts are subrounded and the matrix is similar to that in the alluvial deposits.

\section{DIKES AND IRREGULAR INTRUSIVE MASSES}

Andesite porphyry.-Dark-gray to grayish-black, very fine grained to aphanitic rock with plagioclase phenocrysts, as much as $8 \mathrm{~mm}$ in length, making up at least one-fourth of the rock. Mafic phenocrysts, few, inconspicuous, and usually less than $2 \mathrm{~mm}$ long, of pyroxene, partly altered to hornblende, epidote, or zoisite and smaller magnetite crystals. Groundmass of lathlike plagioclase, magnetite, and acicular hornblende. Intrudes Williamson Canyon Volcanics and diorite; an unmapped dike intrudes a small mass of older quartz latite porphyry in NE $1 / 4$ sec. 1, T. $6 \mathrm{~S} .$, R. $13 \mathrm{E}$.

Younger quartz latite porphyry. - Intrudes latite and rhyolite porphyries. Most latite(?) porphyries are dikes only a few feet wide, very light colored, with platy flow structure; a few very inconspicuous feldspar phenocrysts, mostly less than $2 \mathrm{~mm}$ long, and smaller altered mafic minerals, probably originally hornblende or biotite. Aphanitic to granular groundmass; granular phase probably represents devitrified glass. Distinct from these latite(?) porphyries are the larger (50 to $100 \mathrm{ft}$ wide) dikes of quartz latite or rhyolite $(\mathrm{NW} 1 / 4$ sec. 11, T. 6 S., R. 13 S., and N1/2 sec. 27, T. 5 S., R. 14 E.); very light yellowish, greenish, to pinkish gray with fairly abundant phenocrysts of euhedral to resorbed quartz (1-2 $\mathrm{mm})$ and K-feldspar and altered plagioclase (1-3 $\mathrm{mm}$ ), with or without a few tiny magnetite and altered mafic phenocrysts, in an aphanitic and devitrified groundmass. No age data or chemical analyses are available for any of these rocks. They intrude diorite and some of the rhyodacite porphyry dikes. Also mapped as younger quartz latite porphyry is the 200-ft-wide dike in west-central part of sec. 24, T. 5 S., R. 13 E. It is pale red with a very few tiny phenocrysts of feldspar (some are microcline and may be xenocrysts from the granite), biotite, and quartz in an aphanitic, devitrified groundmass with numeruus 
tiny vugs. Flow structure is well developed. It may be Miocene in age.

Younger rhyodacite porphyry.-Two dikes mapped: (1) one in NE $1 / 4$ sec. 24, T. 5 S., R. 13 E., intruding older quartz latite porphyry (Klo) and an older rhyodacite porphyry (TKrq); (2) one in SE1/4 sec. 25 , T. 5 S., R. 13 E., intruding hornblende andesite porphyry (Kha). Both are medium greenish gray to olive gray with abundant phenocrysts of plagioclase, as much as $7 \mathrm{~mm}$ long, and smaller phenocrysts of hornblende and biotite in an aphanitic groundmass. Chilled margins of both dikes contain smaller and fewer phenocrysts.

Hornblende porphyry. - Medium-gray to greenish- or olive-gray, fine-grained porphyritic to essentially nonporphyritic rocks of probable hornblende andesite to hornblende rhyodacite composition. Many of the dikes are less than $10 \mathrm{ft}$ wide. Most hornblende and the rare feldspar phenocrysts are only slightly larger than groundmass size (1-2 $\mathrm{mm})$, but locally hornblende needle- and lath like crystals are as much as $5 \mathrm{~mm}$ long. Some dikes are darker in color and are characterized by a fine-grained groundmass composed of feldspar and numerous small hornblende needles. The east-trending dike in sec. 27, T. 6 S., R. 14 E., and the north-northwest-trending one that extends from SW1/4 sec. 29 to NE $1 / 4$ sec. 30 , T. 6 S., R. 14 E., are of this type. The northnorthwest-trending dike is cut by east-trending dikes of similar composition but lighter color that have fewer but longer $(5 \mathrm{~mm})$ hornblende crystals. Both types are probably closely related in time and probably of andesitic composition.

Melanocratic rhyodacite porphyry.-Medium-gray rock with a greenish tinge, phenocrysts of plagioclase, quartz, and hornblende. In the large mass north of Tecolote Ranch that intrudes older quartz latite porphyry, plagioclase phenocrysts and somewhat less abundant euhedral to resorbed quartz phenocrysts are $1-10 \mathrm{~mm}$ in diameter and scattered hornblende laths are as much as $8 \mathrm{~mm}$, but mostly less than $3 \mathrm{~mm}$. Groundmass generally granular, not aphanitic, as in most of the rhyodacite porphyry; composed of plagioclase, hornblende, K-feldspar, and magnetite; largely altered to chlorite, calcite, and epidote. Most hornblende phenocrysts are altered; and feldspar is sericitized and saussuritized. Some dikes, tentatively classes as melanocratic rhyodacite, have few or no quartz phenocrysts and (or) small sparsely distributed plagioclase. A few have biotite. As all intrude Ruin Granite and some contain xenoliths of the granite, it is possible that some finegrained mafic rocks with xenocrysts have been mapped as melanocratic rhyodacite porphyry. Chilled margin of the dike along the road about $3 / 4$ mile southeast of Tecolote Ranch resembles dikes mapped as fine-grained quartz diorite in the Winkelman quadrangle (Krieger, 1974a), whereas the chilled margin of the dike that cuts diabase, near the center of west edge of sec. 35, T. 5 S., R. 14 E., resembles fine-grained hornblende porphyry (TKh).

Rhyodacite porphyry.-Dikes, a few feet to more than $200 \mathrm{ft}$ wide, and pluglike to irregular bodies. Mostly aphanitic rocks with abundant phenocrysts of feldspar, less abundant biotite and hornblende, with or without quartz. Those with obvious quartz phenocrysts (TKrq) are medium gray to greenish gray, but light brownish, yellowish, or olive gray where altered; surface weathers to a limonitic brown. Their feldspar and quartz phenocrysts are mostly $1-2 \mathrm{~mm}$, locally 5 or more $\mathrm{mm}$ long; biotite and hornblende phenocrysts are mostly 1-2 $\mathrm{mm}$. Groundmass is aphanitic and mostly creamy to greenish in color. Quartz is resorbed. Alteration products are epidote, chlorite, and opaques.

Dikes with little or no quartz as phenocrysts (TKr) are medium gray to brownish or olive gray with very abundant plagioclase phenocrysts and less abundant phenocrysts of hornblende and biotite in a creamy, aphanitic groundmass. Feldspar phenocrysts, mostly 1-2 $\mathrm{mm}$ in length, locally as much as $1 \mathrm{~cm}$, make up approximately 30 percent of the rock. Hornblende and biotite phenocrysts, usually not more than $1-2 \mathrm{~mm}$ in in largest dimension, generally present in about equal amounts; locally, hornblende is the principal mafic mineral. Where badly altered, feldspar and mafic phenocrysts may be difficult to see on a freshly broken surface. The groundmass is composed of plagioclase, quartz, K-feldspar, hornblende, biotite, and magnetite. Both the groundmass and phenocryst minerals in some dikes are altered to chlorite, epidote, magnetite, and calcite.

Unclassified dikes ${ }^{1}$

\section{DIKES, SILLS, AND IRREGULAR INTRUSIVE MASSES}

Granodiorite.-An irregular mass of granodiorite intrudes Precambrian rocks along the north edge of the quadrangle and east-trending dikes intrude granite and diorite. The granodiorite is identical to, and some of the dikes are "offshoots of, an irregular mass in the Winkelman quadrangle. Biotite from the Winkelman mass dated by the K-Ar method $66.0 \pm 2.0$ m.y. Damon and others (1964, Copper Hill quartz monzonite p. 48) obtained a date of $68 \mathrm{~m} . \mathrm{y}$. on biotite from this mass. The granodiorite is medium-light-gray with a brownish tinge; contains abundant 1-5 mm laths plagioclase, 1-3 $\mathrm{mm}$ books of biotite; $1-5 \mathrm{~mm}$ laths of hornblende, and small magnetite crystals. Fine-grained to aphanitic groundmass in narrower parts of dikes, but only slightly finer grained than the smaller phenocrysts in the larger mass. Groundmass of quartz, K-feldspar, plagioclase, and mafic, and opaque minerals. Most biotite is fresh, some is altered to chlorite; hornblende generally more altered than biotite. Much of the granodiorite in the irregular mass in this quadrangle is badly altered.

Hornblend Diorite. - The dike near the center of the quadrangle (sec. 7, T. 6 S., R. 14 E.) closely resembles the hornblende diorite in the northeast corner of the Winkelman quadrangle; medium gray to medium light olive gray with abundant 1-2 $\mathrm{mm}$ phenocrysts of saussuritized plagioclase and smaller mafic minerals (now altered to chlorite and epidote), magnetite, and

${ }^{1}$ Numerous dikes, sills, plugs, and irregular igneous masses intrude Precambrian rocks, Abrigo Formation, Escabrosa Limestone, and Williamson Canyon Volcanics, and the earlier intrusive rocks. Many are only a few feet wide and greatly exaggerated on the map. Many small ones are not represented. The dikes were classified mainly by comparing hand specimens during the final stages of mapping. The classification was hampered by compositional variations of the dikes along strike and by alteration. Separation of narrow dikes was most difficult because they are multiple, branching, and offset. The intrusive rocks are classified as to relative age; some conclusions are tentative. Where insufficient data were collected, the dikes were lumped as unclassified (TKu). 
very little quartz in a badly altered, very fine grained groundmass.

Diorite-Medium-dark-gray, fine- to medium-grained (mostly less than $2 \mathrm{~mm}$ ), composed of plagioclase, pyroxene, hornblende, biotite, magnetite, and some quartz and $\mathrm{K}$-feldspar. Local alteration products are epidote, chlorite, and sericite. Hornblende from a specimen collected in the Winkelman quadrangle from the eastern extension of the mass north of Crozier Peak gave. an age of $65.6 \pm 2.0 \mathrm{~m}$.y. The diorite may be about the same age (71 m.y., biotite, $82 \mathrm{~m} . y$. , hornblende) as the Tortilla Quartz Diorite in the Sonora quadrangle (see also Banks and others, 1972).

Dacite porphyry.-Medium-gray porphyry with olive tinge; phenocrysts of zoned, twinned, and altered plagioclase less than 1 to about $4 \mathrm{~mm}$ in length; of hornblende, less than 1 to more than $2 \mathrm{~mm}$ in length, and smaller pyroxene and magnetite. Smaller hornblende phenocrysts almost completely altered to granular magnetite; larger ones have narrow rims of magnetite. Groundmass of plagioclase laths, pyroxene(?), and magnetite; spotty areas of epidote, chlorite, and calcite. Joan Engels (written commun., 1968) has dated hornblende from this mass at $71.3 \pm 2.1 \mathrm{~m} . \mathrm{y}$. by the $\mathrm{K}-\mathrm{Ar}$ method. The chemical and normative compositions (table 2 ) indicate a probable dacitic composition.

TABLE 2.-Chemical and normative compositions of hornblende andesite porphyry and dacite porphyry [Analyses under direction of Leonard Shapiro, methods given in U.S. Geol. Survey Bull 1144-A]

\begin{tabular}{|c|c|c|c|c|c|}
\hline Field No. & W-149. & W-169 & & W-149 & W-169 \\
\hline \multicolumn{3}{|c|}{$\begin{array}{c}\text { Chemical composition } \\
\text { (in percent) }\end{array}$} & \multicolumn{3}{|c|}{$\begin{array}{l}\text { C.I.P.W. norms } \\
\text { (wt percent) }\end{array}$} \\
\hline \multirow{13}{*}{$\begin{array}{l}\mathrm{SiO}_{2} \\
\mathrm{Al}_{2} \mathrm{O}_{3} \\
\mathrm{Fe}_{2} \mathrm{O}_{3} \\
\mathrm{FeO} \\
\mathrm{MgO} \\
\mathrm{CaO} \\
\mathrm{Na}_{2} \mathrm{O} \\
\mathrm{K}_{2} \mathrm{O} \\
\mathrm{H}_{2} \mathrm{O} \\
\mathrm{H}_{2} \mathrm{O}^{-} \\
\mathrm{TiO}_{2} \\
\mathrm{P}_{2} \mathrm{O}_{5} \\
\mathrm{MnO} \mathrm{M} \\
\mathrm{CO}_{2}\end{array}$} & \multirow{13}{*}{$\begin{array}{c}55.3 \\
18.5 \\
6.7 \\
.84 \\
2.5 \\
7.8 \\
3.5 \\
1.4 \\
.25 \\
1.7 \\
.94 \\
.22 \\
.17 \\
<.05\end{array}$} & \multirow{13}{*}{$\begin{array}{c}57.3 \\
15.6 \\
.80 \\
6.0 \\
3.8 \\
4.6 \\
3.9 \\
1.8 \\
1.3 \\
2.9 \\
.82 \\
.18 \\
.15 \\
<.05\end{array}$} & $\mathbf{Q}$ & 11.4 & 9.4 \\
\hline & & & or & 8.5 & 11.2 \\
\hline & & & $a b$ & 30.3 & 34.8 \\
\hline & & & an & 31.3 & 20.8 \\
\hline & & & wo & 2.8 & 0.8 \\
\hline & & & en & 6.4 & 10.0 \\
\hline & & & fs & & 9.8 \\
\hline & & & $\mathrm{mt}$ & 0.5 & 1.2 \\
\hline & & & $\mathrm{hm}$ & 6.5 & \\
\hline & & & il & 1.8 & 1.6 \\
\hline & & & ap & 0.5 & 0.4 \\
\hline & & & Total & 100.0 & 100.0 \\
\hline & & & Salic & 81.4 & 76.1 \\
\hline & & & & 18.6 & 23.9 \\
\hline & 100 & 99 & $\begin{array}{l}\text { In calcu } \\
\text { both } \mathrm{H}_{2} \\
\text { omitted }\end{array}$ & $\begin{array}{l}\text { ting th } \\
+ \text { and } 1\end{array}$ & $\begin{array}{l}\text { orms, } \\
\text { o- were }\end{array}$ \\
\hline
\end{tabular}

W-149 - Hornblende andesite porphyry, SE $1 / 4$ sec. 25 , T. 5 S., R. 13 E.

W-169 - Dacite porphyry, SE $1 / 4$ sec. 1, T. 6 S., R. 14 E., just north of Hackberry Wash - Tecolote Ranch road.

Older quartz latite porphyry.-Possibly latitic to rhyolitic in composition. Greenish- to yellowish- and very light brownish-gray rock that weathers nearly white, composed of scattered phenocrysts of plagioclase and altered mafic minerals, mostly 1-2 mm long. Groundmass devitrified and altered; some of it may have been perlitic. Mafic phenocrysts mostly of biotite, locally hornblende. A small mass in $\mathrm{NE}^{1 / 4} \mathrm{sec} .1, \mathrm{~T}$. $6 \mathrm{~S}$., R. 13 E., containing fresh biotite and small magnetite phenocrysts, is correlated with older quartz latite porphyry.

Hornblende andesite porphyry.-Medium-gray rock with a bluish tinge, containing scattered hornblende phenocrysts as much as $1 \mathrm{~cm}$ long. Very fine grained to aphanitic groundmass; abundant small phenocrysts of altered plagioclase, light-green clinoenstatite, and magnetite, mostly less than $1 \mathrm{~mm}$ in diameter; hornblende usually narrowly rimmed by granular magnetite. Spotty chloritization of the groundmass is common. The small offset southern part of the mass is more altered than the northern part, and hornblende phenocrysts are not as obvious. Chemical and normative compositions (table 2) indicate an andesitic to dacitic composition. Hornblende from an identical-appearing dike in the Sonora quadrangle gave a $\mathrm{K}$-Ar age of $128 \mathrm{~m} . \mathrm{y}$., suggesting an Early Cretaceous age (Cornwall and others, 1971; Banks and others, 1972).

\section{VOLCANIC ROCKS}

Rhyodacitic to quartz latitic pyroclastic rocks and flows.-Occurs in two areas:

1. South of upper Jim Thomas Wash extending north from the Hackberry Wash-Tecolote Ranch road for about a mile and a half. Maximum thickness of about $300 \mathrm{ft}$. Poorly exposed, olive-gray to gray flows(?), flow breccias and intrusive(?) rocks containing phenocrysts of plagioclase (1-10 mm), green hornblende(?) $(1-15 \mathrm{~mm})$, and smaller magnetite. Plagioclase and hornblende(?) are badly altered. Epidote occurs in the groundmass and as large areas that probably represent volcanic fragments and (or) xenoliths; also with calcite in vugs. The unit does not resemble the volcanic rocks to the north but may be of essentially the same age. It lies on the east side of the andesite that occurs in the San Manuel Formation, apparently along a major fault, whereas the volcanics west of Jim Thomas Wash are west of (below) the andesite and associated nongranitic alluvial deposits.

2. West of Jim Thomas Wash (maximum thickness of about 1,000 ft).-Composed of volcanic clasts as much as a foot in diameter and smaller lithic and crystal fragments in a matrix of devitrified ash. Matrix mostly light to very light gray and brownish gray. Clasts, mediumlight brownish-gray, purplish-gray and locally moderategray, composed of euhedral to resorbed quartz phenocrysts, as much as $3 \mathrm{~mm}$ in diameter; fresh to sericitized plagioclase, as much as $8 \mathrm{~mm}$ long; fresh to altered hornblende, about $1 \mathrm{~mm}$ long; larger altered biotite, and smaller magnetite; some mafics altered to chlorite, The groundmass of the clasts is cryptocrystalline. Crystal fragments of broken and fractured quartz and plagioclase, fresh hornblende, biotite (now largely altered to chlorite), magnetite, and a little microcline. Matrix, in addition to the finely comminuted lithic and crystal fragments, probably once consisted of shards and pumice, although none were recognized. No evidence of ash-flow origin or flow structure were noted, nor was bedding observed. Southern, wider part may contain latite or andesite flow or massive tuff. The local presence of conglomerate similar to that described below $(\mathrm{Kc})$, beneath the Williamson Canyon Volcanics in the Saddle Mountain quadrangle suggests a correla- 
tion, but those volcanic rocks are andesitic in composition. Some of the volcanic clasts in the pyroclastic rocks are similar in composition and general appearance to some of the flow breccias in the Glory Hole Volcanics (Krieger, 1968b; see also Simons, 1964). The volcanic rocks west of Jim Thomas Wash are intruded by hornblende porphyry and by unclassified dikes.

Basal conglomerate.-Composed of well-rounded large cobbles and small boulders of granitic rocks, quartzite, and a few of porphyry similar to the fragments in the volcanic rocks.

Williamson Canyon Volcanics.-Named by Simons (1964); Willden (1964), called these same rocks "unnamed volcanic and sedimentary rocks." Extend eastward from Eagle Wash to north of Crozier Peak. Darkgray andesite(?) porphyry with phenocrysts of plagioclase as much as $6 \mathrm{~mm}$ long, hornblende rimmed with epidote(?), altered pyroxene, and magnetite, in a very fine grained to aphanitic groundmass of plagioclase, hornblende, pyroxene, biotite, and a little quartz; some chlorite alteration. Closely associated with and intruded by diorite. Contacts with diorite separate areas composed largely of diorite from those composed of volcanics and as much as 50 percent diorite. Abundant xenoliths of Troy Quartzite, granite, and epidotized fragments of Escabrosa(?) Limestone, pebbles to lenses of mappable size. In some places the unit is a volcanic breccia. Except for its finer grain size, the volcanics superficially resemble the diorite. In a few places the diorite is clearly intrusive into the volcanic rocks. Because of their probable andesitic composition, these volcanics are correlated with the Williamson Canyon Volcanics in the Saddle Mountain quadrangle,Christmas quadrangle, and Klondyke quadrangle (Simons, 1964).

ESCABROSA LIMESTONE (0-ABOUT 200 FT IN THIS AREA)

Massive, cliff-forming, thick-bedded, light-colored, fossiliferous, mostly coarse-grained, crystalline limestone, separated by slope- and ledge-forming, thinbedded, dark-colored, fine-grained silty and dolomitic limestone. The basal $38 \mathrm{ft}$ of the formation above the measured section of the Martin Formation is composed of these darker beds. Limestone lenses about one-half mile northwest of the top of Crozier Peak metamorphosed, especially the eastern end of the southern mass, to massive brown and yellow andradite in crystals $0.1-3.0 \mathrm{~mm}$ in diameter, associated with epidote. Limestone lens near Eagle Wash contains considerable epidote. Limestone in both lenses tentatively correlated with the Escabrosa. Because of brecciated character and occurrence in an area where Paleozoic formations in normal sequence are absent, these lenses may represent landslide blocks later caught up in volcanic and intrusive rocks.(Named by Ransome, 1904).

\section{MARTIN FORMATION (MAXIMUM OF ABOUT 275 FT)}

Upper member (0-120 ft thick).-Shale and siltstone, in part dolomitic and calcareous; very thin bedded, yellowish brown to light olive gray, weathers grayish orange. A few thin beds of limestone and dolomite, especially at top.

Lower member (0-155 ft thick). - Dolomite and limestone; brownish gray to olive gray and medium gray; dense to finely crystalline. A few quartzite and calcareous to dolomitic sandstone beds especially in lower part. The upper shaly unit is equivalent of most of the formation in the Holy Joe Peak area (Krieger, 1968a-d), where it is 100 to $250 \mathrm{ft}$ thick, with locally as much as $50 \mathrm{ft}$ of limestone at the top. The lower carbonate unit is equivalent to most of the formation in the Ray and Superior areas (Cornwall and others, 1971 and Peterson 1969). (Named by Ransome, 1904).

Section of Martin Formation measured in Thickness NW $1 / 4$ sec. 30, T. 5 S., R. 14 E., due west (feet) where Jim Thomas Wash swings northeast

Escabrosa Limestone

Martin Formation

Upper member

Limestone, dense, platy, very light brownish gray; weathers light olive gray

Siltstone and shale, dolomitic, very thin bedded, moderate yellowish-brown to light-olive-gray; weathers grayish orange Total thickness of upper member

Lower member

Limestone, crystalline, light-brownishgray; weathers light olive gray, moderately fossiliferous; beds as much as 18 in. thick, locally thin-bedded and silty

Limestone and dolomite, thin-bedded

Limestone, dense, olive-gray to mediumgray; weathers light olive gray to light gray; very fossiliferous at top; fossils include Cyrtospirifer, Stropheodonta, Atrypa, small spiriferoids, and crinoid stems

Sandstone, calcareous, yellowish-gray; weathers nearly white

Limestone, dense, light-olive to greenishgray; weathers very light gray; scattered, rounded, frosted quartz grains

Dolomite, pale-red, thin-bedded

Dolomite and limestone, poorly exposed

Sandstone, or quartzite, very light gray with pinkish-tinge, medium-grained

Limestone, fine grained, brownish-gray; weathers light olive gray, thinly laminated

Red, hematitic bed

Limestone, crystalline, dark-gray (sparkly); weathers medium to dark gray, thinly laminated; probably equivalent to the host rock for ore bodies in the Magma mine at Superior and the Christmas mine ${ }^{1}$

Total thickness of lower member

Total thickness of Martin Formation

Abrigo Formation

${ }^{1}$ In some places a light-gray dense carbonate bed underlies the dark-gray ore horizon, and a 10 - to 25 - $\mathrm{ft}$ bed of quartzite overlies it

Remarks on Abrigo Formation (About $268 \mathrm{ft}$ )

The formation consists of three members east of the San Pedro River (Krieger, 1968a-c). Middle member unmapped, generally absent, or only a few feet thick; 52 feet thick below measured section of Martin Formation. Very fine grained, well-sorted orthoquartzite with a few silty interbeds. 


\section{LOWER MEMBER OF ABRIGO FORMATION}

(216 ft measured, see measured section for location) Pale-yellowish-brown to olive gray sandy mudstone, claystone, and siltstone with some beds of dolomite and sandstone; thin-bedded, with very irregular bedding surfaces; very similar to the member in the Holy Joe Peak area (Krieger, 1968a-e). Dolomite most abundant near the middle of the member. Quartzite or coarsegrained sandstone with abundant phosphatic brachiopods; some dolomitic sandstone $50 \mathrm{ft}$ below the top in the area where the Martin was measured. Locally, basal $5 \mathrm{ft}$ and uppermost $10 \mathrm{ft}$ are quartzite containing phosphatic brachiopods. At $5 \mathrm{ft}$ mafic (trachytic) sill occurs about $100 \mathrm{ft}$ above the base. Mudstone member generally rests directly on Troy Quartzite, but locally a few feet of thin-bedded, fine- to medium-grained banded sandstone overlies and appears to grade downward into typical pebbly Troy Quartzite. Most of this sandstone is believed to belong in the Troy, but some of it resembles thin beds at the top of the Middle Cambrian Bolsa Quartzite (not present in this quadrangle); in one place an angular clast of quartzite, probably Troy, was observed. (Named by Ransome, 1904).

DIABASE

Dark-gray to dark-greenish- or olive-gray, fine- to coarse-grained rocks with diabasic to ophitic texture; composed of plagioclase, pyroxene, olivine, magnetite, and ilmenite; little K-feldspar and quartz; some chlorite, epidote, sericite, and calcite alteration. The wider sills(?) (200-400 ft) that are well below the pre-Apache surface are identical to the known Precambrian diabase sills that occur in the Apache Group or within $500 \mathrm{ft}$ below the pre-Apache surface. Their present distribution may be explained by known or probable faults. Some of the narrow (a few feet to $500 \mathrm{ft}$ ) dikes(?) or sill-like masses were questionably correlated with the Precambrian diabase, as they (Nos. 1-3, table 3) contain more $\mathrm{SiO}_{2}$ than and about half the $\mathrm{TiO}_{2}$ of known Precambrian diabase in the Sierra Ancha (Nos. 4-6, table 3) (A.F. Shride, written communication,1968). Recent chemical analyses of thick diabase sills in the Brandenburg Mountain quadrangle (Nos. 7-9, table 3), however, are very similar to the narrow masses in this quadrangle in $\mathrm{SiO}_{2}$ and $\mathrm{TiO}_{2}$ content. No chemical analyses of the thicker sills in the Crozier Peak quadrangle are available, and none have been dated at yet. The constituent minerals in the narrow dikes and sills are usually too altered to give an age date on hornblende or biotite. Felsic dikes with hornblende needles that cut some of the large sills of diabase probably are differentiates of the diabase.

\section{TROY QUARTZITE (ABOUT 700 FT)}

Originally considered Cambrian in age (Ransome, 1915), but now known to be Precambrian, as it is intruded by diabase and unconformably overlain by Cambrian and (or) Devonian rocks (Krieger, 1961, 1968a-e; Shride, 1967). Roughly separated into two units, both probably equivalent to the Chediski Sandstone Member of the Troy Quartzite (Shride, 1967).

Upper unit (about $450 \mathrm{ft}$ ). - White to very light gray and grayish-red, thin- to thick-bedded, feldspathic and nonfeldspathic sandstone, quartzite, and conglomerate, with clasts largely of quartz, mostly less than $1 / 2$ inch in diameter; granules and pebbles are concentrated in upper few inches of many beds. Locally fine to medium grained with thin beds and laminae of pinkish gray to very pale reddish brown sandstone near top of unit.
Leisegang banding, not parallel to bedding, also common. Lower unit $165 \mathrm{ft}$ thick in $S E^{1 / 4} \mathrm{sec} .24, T$. $5 \mathrm{~S}$., $R$. 13 E.).-Dark-brownish-gray outcrops of mediumgray to pale-red conglomerate and sandstone, mostly thin-bedded and lenticular; thin beds of greenish-gray argillite; clasts of quartz and quartzite (some well rounded) and angular pieces of pink feldspar. Upper part consists of light-bluish-gray beds of fine-grained sandstone with scattered well-rounded pebbles. Local convolute laminations.

\section{APACHE GROUP}

Group, formations, and members named by Ransome (1903) except for Mescal Limestone (Ransome, 1915) and siltstone and arkose members of the Dropping Spring Quartz (Shride, 1967).

\section{BASALT (0-ABOUT 50 FEET)}

Local remnants between Mescal Limestone and Troy Quartzite, SE $1 / 4$ sec. 13, to $\mathrm{NE}^{1 / 4}$ sec. 25 , T. $5 \mathrm{~S}$., R. 13 E. Blackish-red to grayish-red and brownish-black porphyritic, amygdaloidal, vesicular basalt (see Shride, 1967, p. $42-44$, for fuller discussion).

\section{MESCAL LIMESTONE (200-300 FT)}

Thin- to thick-bedded, brown to pale-red, dense to finely crystalline dolomite and cherty dolomite, some calcareous dolomite and silty dolomite; weathers brown to light gray. Locally metamorphosed by diabase to white silicate-bearing calcic limestone. Base of the formation is 0 to $15 \mathrm{ft}$ of brown, coarse-grained sandstone in a dolomitic matrix. About $20 \mathrm{ft}$ above the base is a dolomite with conspicuous irregular black chert layers and lenses parallel to bedding. It is separated from the underlying basal sandstone by about $2 \mathrm{ft}$ of light-gray dolomite. Probably consists largely of the lower member of the Mescal (Shride, 1967, p. 25-42), as no algal structures, characteristic of the overlying algal (middle) member of the formation, were noted. The 293-ft section on the top of the east-trending ridge about $1,200 \mathrm{ft}$ north of the southern border of sec. 24 , T. 5 S., R. 13 E., is thicker than known sections of the lower member elsewhere.

\section{DRIPPING SPRING QUARTZITE (350-500 FT)}

Siltstone member (about $250 \mathrm{ft}$ ). - Thin-bedded, thinly laminated siltstone and very fine grained feldspathic to arkosic quartzite in shades of gray, brown, red, and yellow. A white to light-gray, medium-to coarse-grained quartzite, 25-50 ft thick, occurs near the middle of the member. It was not recognized everywhere but is prominent in the southernmost part of Ripsey Hill ridge, east of Tecolote Ranch. Granger and Raup (1964) subdivided the member into four units.

Arkose member (150-200 ft).-Mostly medium-grained thin- to thick-bedded, cross bedded, red to pink feldspathic to arkosic quartzite.

Barnes Conglomerate Member (10-50 ft). - Ellipsoidal, well-rounded pebbles ( $1 / 4$ - 6 in.) of quartzite, quartz, and red jasper, mostly closely packed, locally sparsely scattered, in a matrix of red to gray, coarse-grained arkosic sandstone or quartzite.

\section{PIONEER FORMATION}

(150 - nearly 300(?) ft; maximum thickness uncertain because of poor exposures, possibility of unmapped sills of diabase and Late Cretaceous and(or) early Tertiary intrusive rocks, and unmapped lenses of Pioneer within the sills.)

Upper member.-Dark-red to purple siltstone and very fine grained sandstone with numerous pale-red to 
TABLE 3.-Chemical and normative compositions of narrow sills or dikes of diabase, compared with large sills of Precambrian age in Gila County and Aravaipa Canyon

[Analyses under direction of Leonard Shapiro, methods given in U.S. Geol. Survey Bull. 1144-A, except in Y-19-64, Y-9-64, and Y-24-64, analyzed by C.L. Parker, methods given in U.S. Geol. Survey Bull. 1170]

\begin{tabular}{|c|c|c|c|c|c|c|c|c|c|}
\hline Field No. & $\begin{array}{c}1 \\
\text { W-1 } \\
\end{array}$ & $\begin{array}{c}2 \\
W-192 \\
\end{array}$ & W-210 & $\begin{array}{c}4 \\
Y-19-64 \\
\end{array}$ & $\begin{array}{l}5 \\
Y-94 \\
\end{array}$ & $Y-24-64$ & $\begin{array}{c}7 \\
\mathrm{~A}-10 \\
\end{array}$ & $\begin{array}{c}8 \\
A-11 \\
\end{array}$ & $\begin{array}{r}9 \\
A-12 \\
\end{array}$ \\
\hline & & $\cdot$ & \multicolumn{4}{|c|}{ Chemical composition (in percent) } & \multicolumn{3}{|c|}{$\cdot$} \\
\hline $\mathrm{SiO}_{2}$ & 52.3 & 52.4 & 49.9 & 45.50 & 46.23 & 46.70 & 49.3 & 51.2 & 49.2 \\
\hline $\mathrm{Al}_{2} \mathrm{O}_{3}$ & 13.1 & 13.4 & 15.3 & 16.69 & 16.07 & 18.78 & 16.2 & 14.5 & 15.9 \\
\hline $\mathrm{Fe}_{2} \mathrm{O}_{3}$ & 10.9 & 5.8 & 3.5 & 2.45 & 1.73 & 2.08 & 2.2 & 2.5 & 2.5 \\
\hline $\mathrm{Fe} 0$ & 3.9 & 8.4 & 5.1 & 10.48 & 10.49 & 8.78 & 9.1 & 8.3 & 8.8 \\
\hline Mg0 & 4.2 & 4.4 & 9.3 & 6.07 & 8.49 & 6.75 & 6.4 & 6.3 & 6.9 \\
\hline $\mathrm{Ca} 0$ & 6.6 & 6.1 & 8.2 & 7.28 & 9.63 & 8.51 & 9.5 & 10.5 & 9.7 \\
\hline $\mathrm{Na}_{2} \mathrm{O}$ & 2.6 & 2.5 & 3.2 & 3.02 & 2.76 & 3.33 & 2.7 & 2.5 & 2.7 \\
\hline $\mathrm{K}_{2} \mathrm{O}$ & 1.9 & 2.2 & .73 & 1.72 & .61 & .76 & 1.0 & .79 & .91 \\
\hline $\mathrm{H}_{2} \mathrm{O}$ & .15 & .41 & .14 & .25 & .08 & .13 & .20 & .14 & .19 \\
\hline $\mathrm{H}_{2} \mathrm{O}+$ & 2.1 & 1.8 & 3.0 & 2.90 & 1.00 & 1.51 & 1.1 & 1.0 & .81 \\
\hline $\mathrm{TiO}_{2}$ & 1.6 & 1.7 & .97 & 2.79 & 2.43 & 2.09 & 1.3 & 1.1 & 1.3 \\
\hline $\mathrm{P}_{2} \mathrm{O}_{5}$ & .26 & .25 & .21 & .44 & .27 & .32 & .20 & .16 & .20 \\
\hline Mno & .25 & .46 & .18 & .19 & .19 & .16 & .17 & .18 & .17 \\
\hline $\mathrm{CO}_{2}$ & .05 & .05 & .05 & .01 & .03 & .04 & .05 & .05 & .05 \\
\hline $\mathrm{Cl}$ & --- & --- & --- & .19 & .12 & -- & --- & -- & $\ldots$ \\
\hline $\mathbf{F}$ & --- & --- & -- & .05 & .03 & .04 & --- & -- & --- \\
\hline Sub total & -- & -.- & ... & 100.03 & 100.16 & 100.10 & --- & -- & --- \\
\hline Less 0 & --- & -- & -- & .06 & .04 & .05 & -- & -- & $-\cdots$ \\
\hline Total & 100 & 100 & 100 & 99.97 & 100.12 & 100.05 & 99 & 99 & 99 \\
\hline \multicolumn{10}{|c|}{ CIPW norms (wt percent) } \\
\hline$Q$ & 13.5 & 8.9 & --- & -.- & ... & -- & ... & 2.3 & -.- \\
\hline or & 11.5 & 13.3 & 4.5 & 10.5 & 3.6 & 4.6 & 6.0 & 4.8 & 5.5 \\
\hline$a b$ & 22.5 & 21.7 & 28.0 & 26.4 & 23.6 & 28.7 & 23.3 & 21.6 & 23.2 \\
\hline an & 18.9 & 19.3 & 26.1 & 27.8 & 30.0 & 34.6 & 29.7 & 26.5 & 29.1 \\
\hline wo & 5.4 & 4.2 & 6.1 & 2.7 & 6.8 & 2.5 & 7.1 & 10.7 & 7.7 \\
\hline en & 10.7 & 11.2 & 19.0 & 1.9 & 4.4 & 1.9 & 12.3 & 16.0 & 12.8 \\
\hline fs & --- & 8.9 & 4.3 & 1.6 & 3.0 & 1.3 & 10.0 & 11.9 & 9.1 \\
\hline fo &.- & --- & 3.5 & 9.6 & 11.9 & 10.6 & 2.8 & --- & 3.3 \\
\hline $\mathrm{fa}$ & -- & --- & 0.9 & 9.1 & 8.8 & 7.8 & 2.5 & $\ldots$ & 2.6 \\
\hline $\mathrm{mt}$ & 9.0 & 8.6 & 5.3 & 3.7 & 2.5 & 3.1 & 3.3 & 3.7 & 3.7 \\
\hline $\mathrm{hm}$ & 5.0 & $\cdots$ & --- & 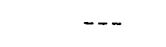 & -- & --- & -.- & --- &.- \\
\hline il & 3.1 & 3.3 & 1.9 & 5.5 & 4.7 & 4.0 & 2.5 & 2.1 & 2.5 \\
\hline ap & .6 & .6 & .5 & 1.1 & .6 & .8 & .5 & .4 & .5 \\
\hline $\mathrm{cc}$ & $\ldots$ & --- & -- & .02 & .1 & .1 & --- & $--\cdot$ & -- \\
\hline Total $^{1}$ & 100 & 100 & 100 & 99.92 & 100 & 100 & 100 & 100 & 100 \\
\hline Salic & 66.2 & 63.2 & 58.6 & 64.8 & 57.2 & 67.9 & 59.0 & 55.2 & 57.7 \\
\hline Femic & 33.8 & 36.8 & 41.4 & 35.7 & 42.8 & 32.1 & 41.0 & 44.8 & 42.2 \\
\hline
\end{tabular}

\footnotetext{
${ }^{1}$ In calculating the norms, $\mathrm{H}_{2} \mathrm{O}+$ and $\mathrm{H}_{2} \mathrm{O}$ - were omitted
}

W-181 A - North-south dike or sill near east edge, SE $1 / 4$ sec. 14, T. 5 S., R. 13 E.

W-192 - North-south dike or sill north edge of map area. NW1/4 sec. 14, T. 5 S., R. 13 E.

W-210 - Northeast-trending dike, SE $1 / 4$ sec. 34, T. 5 S., R. 14 E.

Y-19-64 - Diabase, chilled border, lower contact, 780-ft sill, Sierra Ancha; data from A.F. Shrider (written commun., 1968).

Y-9-64 - Fresh olivine diabase from $450 \mathrm{ft}$, above base of 780 -ft sill; data from A.F. Shrider (written commun., 1968).

Y-24-64 - Coarse-grained diabase in olivine-rich lower one third of 780-ft sill, $200 \mathrm{ft}$ above base; data from A.F. Shride (written commun.,1968).

A-10 - Middle or older sill, west of Aravaipa Canyon, southeast of Brandenburg Mountain, Brandenburg Mountain quadrangle; data from C.F. Wracke, (written commun., 1970).

A-11 - Upper chilled border of younger sill; same location and source of data as No. A-10.

A-12 - Younger sill $12 \mathrm{ft}$ above base; same location and source of data as No. A-10. 
yellowish-gray elliptical leached spots; interbedded with grayish-orange-pink, fine- to medium-grained, crossbedded arkosic sandstone and some dark-red to purple, coarse-grained sandstone; many beds tuffaceous.

Scanlan Conglomerate Member(0-about $30 \mathrm{ft})$.-Subangular to round pebbles and cobbles of quartz and quartzite in a fine- to coarse-grained arkosic sandstone. Locally the conglomerate is very similar in appearance to the Barnes Conglomerate Member of the Dripping Spring Quartzite. In other places, it consists largely of fine- to coarse-grained arkosic sand that, except for scattered small angular to rounded pieces of quartz and granite, or some dark silty beds, could easily be mistaken for the underlying granite.

APLITE

Narrow dikes of pinkish- to yellowish-gray aplite in Ruin Granite; larger areas, shown as aplite, include porphyritic alaskite in an aplitic groundmass as well as Ruin Granite. Most of the aplite probably is related to the Ruin Granite, but some of it may be the younger aplites that cut Cretaceous granodiorite and diorite in adjacent areas.

\section{RUIN GRANITE}

Named by Ransome, (1903); same as Oracle Granite of N.P. Peterson (1938). Coarse-grained, porphyritic, pinkish- to yellowish-gray quartz monzonite, speckled with dark biotite books, as large as $5 \mathrm{~mm}$, and containing euhedral, somewhat poikilitic and perthitic phenocrysts of microcline and microperthite, as large as $4 \times 2 \mathrm{~cm}$; zoned and sericitized plagioclase, mostly less than $1 \mathrm{~cm}$; quartz as rounded crystals, about $6 \mathrm{~mm}$, and as finer intergrowths with microcline; accessory magnetite and apatite; biotite locally altered to a mixture of magnetite and chlorite. Dikes, lenses, and irregular masses of pale-red to pinkish-gray aplitic alaskite porphyry and aplite associated with the granite. These finer grained rocks locally abundant in the granite and, because of their resistance to erosion, form many of the ridge tops. Biotite from the Ruin Granite near Oracle gave an age of $1,420 \mathrm{~m} . \mathrm{y}$. by the K-Ar method (Damon and others, 1962). According to Silver (1968), the age of granite (quartz monzonite) in Arizona, based on $\mathrm{U}-\mathrm{Pb}$ isotope systems in zircon, is $1,430-1,460$ m.y.

\section{REFERENCES}

Banks, N.G., Cornwall, H.R., Silberman, M.L., Creasey, S.C., and Marvin, H.R. 1972, Chronology of in trusion and ore deposition at Ray, Arizona: Econ, Geology. Part 1, K-Ar ages: v 67, p. 864-878.

Cornwall, H.R., Banks, N.G., and Phillips, C.H., 1971, Geologic 'map of the Sonora quadrangle, Pinal and Gila Counties, Arizona: U.S. Survey Geol. Quad. Map GQ-1021, scale 1:24,000.

Cornwall, H.R., and Krieger, M.H., 1974, Geologic map of the Kearny quadrangle, Pinal County, Arizona: U.S. Geol. Survey Geol. Quad. Map GQ-1188, scale $1: 24,000$ (in press).

Creasey, S.C., 1965, Geology of the San Manuel area, Pinal County, Arizona: U.S. Geol. Survey Prof. Paper $471,64 \mathrm{p}$.

1967, General geology of the Mammoth quadrangle, Pinal County, Arizona: U.S. Geol. Survey Bull.1218, 94 p.

Damon, P.E., Livingston, D.E., and Erickson, R.C., 1962, New K-Ar dates of the Precambrian of Pinal, Gila, Yavapai, and Coconino Counties, Arizona, in
New Mexico Geol. Soc. Guidebook, 13th Field Conf., Mogollon Rim Region, east-central Arizona, p. 5657.

Damon, P.E., Mauger, R.L., Bikerman, Michael, 1964, $\mathrm{K}$-Ar dating of Laramide plutonic and volcanic rocks within the Basin and Range province of Arizona and Sonora: Internat. Geol. Cong. 22d, India, Part 3,Proc. Sec. 3, p. 45-55.

Granger, H.C., and Raup, R.B., 1964, Stratigraphy of the Dripping Spring Quartzite, southeastern Arizona: U.S. Geol. Survey Bull. 1168, 119 p.

Heindl, L.A., 1963, Cenozoic geology in the Mammoth area, Pinal County, Arizona: U.S. Geol. Survey Bull. 1141-E, $41 \mathrm{p}$.

Krieger, M.H., 1961, iroy quartzite (younger rrecambrian) and Bolsa and Abrigo Formations (Cambrian), northern Galiuro Mountains, southeastern Arizona, in Geological Survey research 1961: U.S. Geol. Survey Prof. Paper 424-C,.p. C160-C164.

1968a, Geologic map of the Brandenburg ivountain quadrangle, Pinal County, Arizona: U.S. Geol. Survey Geol. Quad. Map GQ-668, scale 1:24,000.

$1968 b$, Geologic map of the Holy Joe Peak quadrangle, Pinal County, Arizona: U.S. Geol. Survey, Geol. Quad. Map GQ-669, scale 1:24,000.

$1968 \mathrm{c}$, Geologic map of the Lookout Mountain, Pinal County, Arizona: U.S. Geol. Survey, Geol. Quad. Map GQ-670, scale $1: 24,000$.

1968d, Geologic map of the Saddle Mountain quadrangle, Pinal County, Arizona, U.S. Geol. Survey, Geol. Quad. Map GQ-671, scale 1:24,000.

1968e, Stratigraphic relations of the Troy Quartzite (younger Precambrian) and the Cambrian formations in the southeastern Arizona, in Southern Arizona Guidebook III (Geol. Soc. America, Cordilleran Sec., 64th Ann. Mtg., Tucson 1968): Tucson, Ariz., Arizona Geol. Society, p. 22-32.

1974a, Geologic quadrangle map of Winkelman quadrangle, Pinal County, Arizona: U.S. Geol. Survey Geol. Quad. Map GQ-1106, scale 1:24,000 (in press)

1974c, Geologic map of the Black Mountain quadrangle, Pinal County, Arizona: U.S. Geol. Survey Geol. Quad Map GQ-1 108, scale 1:24,000 (in press).

1974d, Geologic map of the Putnam Wash quadrangle, Pinal County, Arizona: U.S. Geol. Survey Quad. Map GQ-1 109, scale 1:24,000 (in press).

1974, Regional geologic and structural setting of the Winkelman 15-minute quadrangle, Arizona: U.S. Geol. Survey Jour. Research (in press).

Krieger, M.H., Cornwall, H.R., and Banks, N.G., 1974, The Big Dome Formation and revised Tertiary stratigraphy in the Ray-San Manuel area, Arizona: U.S. Geol. Survey Bull. 1394-A,p. A 54-A62.

Peterson, D.W., 1969, Geologic map of the Superior quadrangle, Pinal County, Arizona: U.S. Geol. Survey Geol. Quad. Map GQ-818, scale 1:24,000.

Peterson, N.P., 1938, Geology and ore deposits of the Mammoth mining camp area, Pinal County, Arizona: Arizona Bur. Mines Bull. 144, geol. ser. 11 (Arizona Univ. Bull., v. 9, no. 2), 63 p.

Ransome, F.L., 1903, Geology of the Globe copper district, Arizona: U.S. Geol. Survey Prof. Paper 12, $168 \mathrm{p}$. 
1904, The geology and ore deposits of the Bisbee quadrangle, Arizona: U.S. Geol. Survey Prof. Paper 21, $168 \mathrm{p}$.

1915, The Paleozoic section of the Ray quadrangle, Arizona: Washington Acad. Sci. Jour., v. 5, p. 380-385.

1919, The copper deposits of Ray and Miami, Arizona: U.S. Geol. Survey Prof. Paper 115, 192 p.

Shride, A.F., 1967, Younger Precambrian geology in southern Arizona: U.S. Geol. Survey Prof. Paper 566, $89 \mathrm{p}$.

Silver, L.T., 1960, Age determinations on Precambrian diabase differentiates in the Sierra Ancha, Gila
County, Arizona [abs.]: Geol. Soc. America Bull., v. 71 , no. 12 , pt.2, p. 1973-1974.

1968, Precambrian batholiths of Arizona [abs.] :

Geol. Soc. America, Cordilleran Sec., 64th Ann. Mtg., Tucson, Ariz. Program, p. 109-1 10.

Simons, F.S., 1964, Geology of the Klondyke quadrangle, Graham and Pinal Counties, Arizona: U.S. Geol. Survey Prof. Paper 461, 173 p.

Willden, Ronald, 1964, Geology of the Christmas quadrangle, Gila and Pinal Counties, Arizona: U.S. Geol. Survey Bull. 1161-E, p. E1-E64. 